Dr. Harold E. Raugh, Jr.

\title{
THE HUNGARIAN MILITARY HISTORY INSTITUTE AND MUSEUM: PRESERVING AND PERPETUATING MILITARY HISTORY AND HERITAGE
}

\section{DOI: $\underline{10.35926 / H D R .2020 .1 .8}$}

The Royal Hungarian Honvéd Army, one of the four components of the Austro-Hungarian armed forces from 1867 to 1918, was dissolved after its defeat in World War I. The Great War, however, served as the impetus for collecting military memorabilia, artifacts, and "an enormous amount of war booty" (p. 22), and consolidating them in one location with the Hungarian Ministry of Defense's wartime archives. In the chaos that followed the collapse of the monarchy and defeat in the war, farsighted officers were instrumental in instituting the Hungarian Military History Archives and the Military History Museum in late 1918. This is the predecessor of the current Hungarian Military History Institute and Museum.

The following century was tumultuous for the Hungarians. Immediately after World War I, the country became the Hungarian Soviet Republic until Admiral Miklós Horthy established a regency in 1920 that lasted until 1944 and included "affiliation" with Germany during World War II. The Soviet Army occupied Hungary in 1944, and five years later the country was declared the "People's Republic of Hungary" under Communist domination. The Stalinist era was punctuated by the 1956 pro-democracy revolt that was crushed by Soviet tanks, after which the Communist government reasserted itself. In late 1989, the provisional President of the Republic declared the end of the Hungarian People's Republic and the establishment of the Hungarian Republic. Hungary has been a democratic nation since that time and a member of the European Union since 2004.

This well-written and nicely crafted book chronicles the evolution of the organization, mission, and functions of the Hungarian Military History Institute and Museum. The physical building of the Museum, located in the Buda Castle complex in Budapest and providing a panoramic view over the Danube River, as well as its cannon-filled courtyard, are also described in detail. The majority of this volume is devoted to "Collections of the Military History Museum," and consists of twenty sub-sections, each focusing on a specific collection, such as edged weapons, modern firearms, uniforms and equipment, fine arts, archaeological artifacts, manuscripts and documents, and the photo archives. Each section is profusely illustrated with fascinating full color images of the various collections' contents, thus opening a window through which to view vignettes of the Hungarian Army and its leaders though the Museum's vast and well-preserved collection.

The last two chapters of this study highlight the Military History Institute and, impressively, the Military History Archives and the Central Archives. The Military History Archives currently holds historically significant documents from some 4,004 military organizations and individuals, totaling about 7,800 linear meters of paper (with digitization efforts in progress), with another 9.5 million microfilm "shots". The 25-page section on 


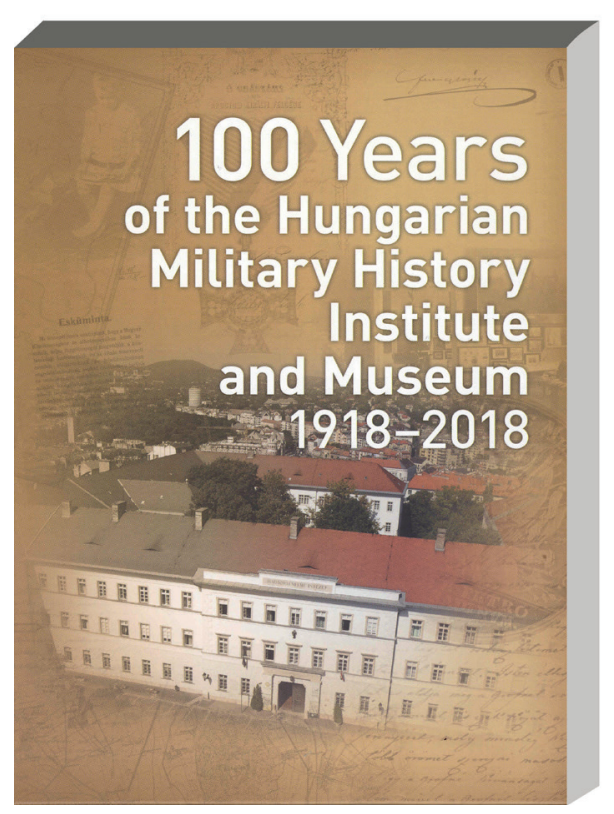

"The Military History Map Collection" that contains over 400,000 maps and aerial images, is remarkably interesting and informative.

Full of enthralling details and marvelous color photographs, 100 Years of the Hungarian Military History Institute and Museum, 1918-2018, sets the standard for chronicling an army's endeavors - highly successful in this case - to preserve and perpetuate its military history and heritage.

Sallay, Gergely Pál, ed. 100 Years of the Hungarian Military History Institute and Museum, 19182018. Budapest: MoD Military History Institute and Museum, 2018. 240 p. 